Portland State University

PDXScholar

\title{
A Comparison of Concepts of the Basic Underlying Assumptions of the Introductory Speech Communication Course in the Oregon Community Colleges as Seen by Speech Communication Faculty and Self-Reported by Students
}

Vickie L. Hilgemann

Portland State University

Follow this and additional works at: https://pdxscholar.library.pdx.edu/open_access_etds

Part of the Communication Commons, and the Education Commons

Let us know how access to this document benefits you.

\section{Recommended Citation}

Hilgemann, Vickie L., "A Comparison of Concepts of the Basic Underlying Assumptions of the Introductory Speech Communication Course in the Oregon Community Colleges as Seen by Speech Communication Faculty and Self-Reported by Students" (1975). Dissertations and Theses. Paper 2126.

https://doi.org/10.15760/etd.2124

This Thesis is brought to you for free and open access. It has been accepted for inclusion in Dissertations and Theses by an authorized administrator of PDXScholar. Please contact us if we can make this document more accessible: pdxscholar@pdx.edu. 
AN ABSTRACT OF THE THESIS OF Vickie Hilgemann for the Master of

Science in Speech presented June 5, 1975.

Title: A Comparison of Concepts of the Basic Undérlying Assumptions

, of the Introductory Speech. Course in the Oregon Community

Colleges As Seen By Speech Faculty and Self-Reported By

Students.

APPROVED BY MEMBERS OF THE THESIS COMMITTEE:

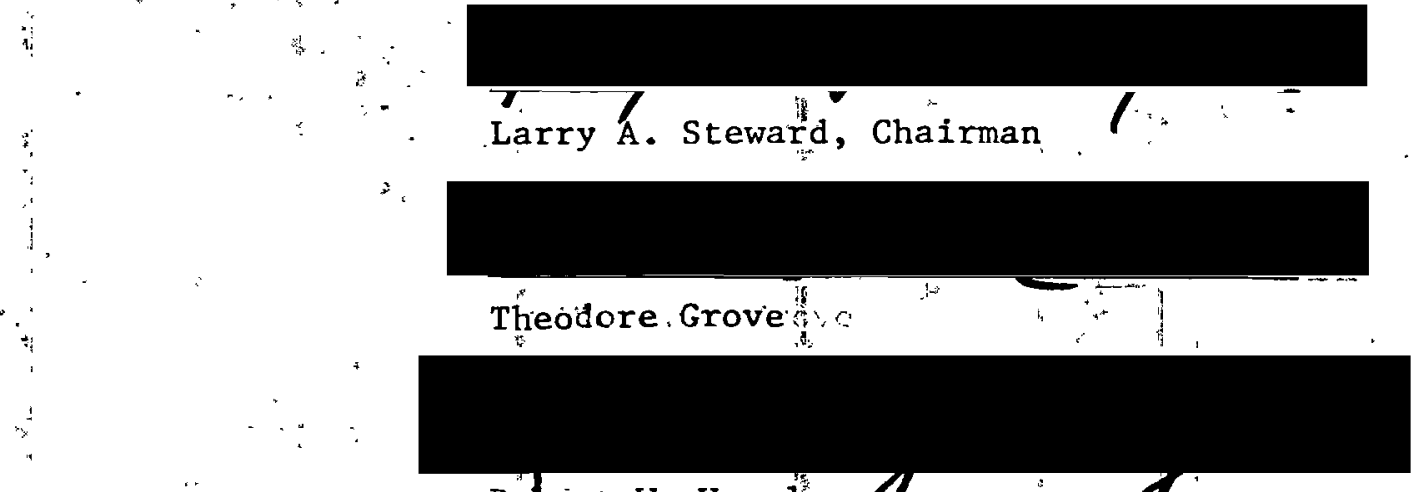

Robert W. Vogel sand

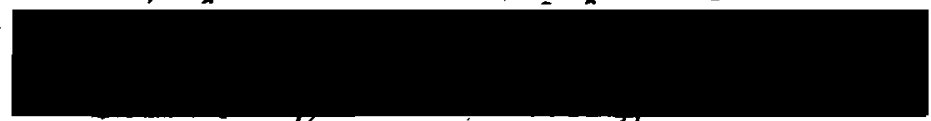

George v. Guy

This study is focused upon an investigation of the content and methodology of the introductory speech course in the Oregon community colleges. The current content appears to be one of an emphasis on skill building in the area of public speaking.

Previous research in the área of content and methodology of the basic course have centered on the courses offered at four-year institutions and has asked only faculty and administrators what they felt should be offered in the introductory course. This research study will instead question students and faculty at the vocational level in the community colleges of oregon to see if there is a similarity in their concepts of what should be taught in this course." 
An answer to the following question was sought: To what extent are the underlying assumptions of the basic speech courses at the community college level as seen by the instructors similar to or different from the self-reported needs in communication training of the community college student?

Two hundred and eighty-four community côllege students from three different colleges and twenty-eight out of a possible forty-four speech faculty in oregon were the basis of this study. The categories used in the questionnaire were defined by use of pre-test data gathered from students in the basic speech course at Chemeketa Community college

The student segment of the study were asked to rank eight groups of five communicative situations each. First they ranked according to what they judged were most important for them to do well. Secondly, they were to rank the same situations according to what they judged they needed the most improvement. The faculty were asked three questions: what they felt that students wanted from the basic course: needed to get from the basic course; and what they were actually getting from the basic course. Data from both questionnaires were then compared by use of the Kendall Coefficient of Concordance, the Friedman Two-Way Analysis, and the spearman Ränk Correlation Coefficient. These hypotheses were tested, and the principal findings, are as follows: Hypothesis I: There is a positive correlation between the basic assumptions of the introductory speech course as seen by the speech instructor and the student-felt needs in this course. 
This hypothesis failed to be confirmed. There appeared to be no significant correlation between what the faculty think are the basic necas of the course and what the students feel fare the basic needs of the introductory course. 'In fact; most of the comparisons appeared to be negative.

There was also some interest as to whether the students agree among themselves as to the basic needs of the course." Thus, the second hypothesis evolved. Hypothesis II: There is a positive correlation between what students feel they need to improve in "ommunicative-wise (societal needs) and what they feel is most important for them 'to do wèll in communicative-wise (personal' needs).

This hypothesis also failed to be confirmed. The correlation between these two sections of the students "questionnaire was not strong enough to be considered significant. It seems that the students do feel there is a difference in these two need areas. It sêems that students then do have the ability to describe what they feel they need in the introductory course.

The same questions had to be asked of the faculty questionnaire. Thus evolves the following three hypotheses and findings:

Hypothesis III: There is a high degree of consistency between what the speech faculty feel are studerts' needs in communication in the introductory speech course and what they . perceive that students get from the introductory speech course.

Hypothesis IV: There is a high degree of consistency between what speech faculty feel that students' needs are in 
Hypothesis $\mathrm{V}$ : There is a high degree of consistency between what the

communication in the introductory speech course and how the faculty perceive what students deem as their communicative needs. speechfaculty feel students deem as their communicative needs in the introductory course and "what they perceive that students get from the introductory course.

These hypotheses were confirmed. Thus, it appears that there is a relationship between what the faculty feel that the students need, want, and get from the introductory course. The facuity seem to think that the current course in speech is giving the studeñts what they want and need. The obvious discrepancy between the results of what the students had to say about their needs and wants, and what the faculty perceived these to be. leads to the basic conclusion of this study. The students are not getting what they feel they need from the basic course. The faculty and perhaps, even the administration of commity colleges, are not communicating with their students as to what should be offered in the basic course in speech. This probably comes from the philosophy that the teacher knows best what the student needs. The current curriculum development in schools' usually provide no formal method of getting student inpüt.

Further research in the area of student needs in the introductory speech course at the community. college level is needed in the following areas:"

1. A description of the current curriculum and methodology used." in the introductory speech course both at the commity college and fouryear college level is needed. 
2. An analysis of what students needs are in the communication ' An analysis of what students needs are

area is needed on a much more comprehensive and sophisticated level

than in this study.

3. A study into curriculum development methods that would best meet student-felt needs in the introductory speech course is needed. Some way must be found to open the communication lines from student to faculty. 


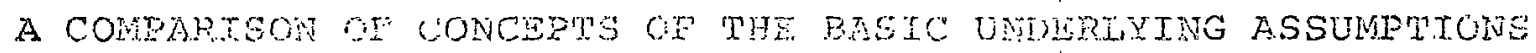

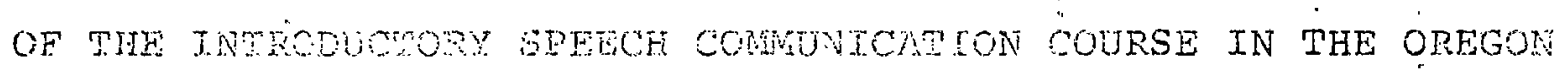

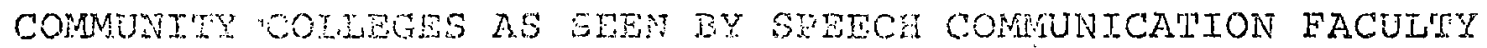

AND SELP-RERORTED BY STUDENTS

by

VICIIE L. HILGENANN

A thesis submitted in partial fulfillment of the requiremerts For the degree of

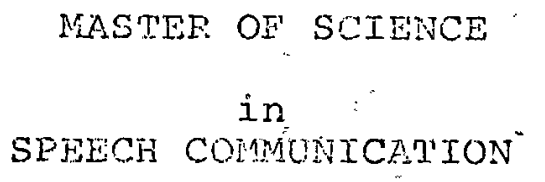

Fortland Staide University

19.75 
TO THE OFFICE OF GRADUATE STUDIES AND RESEARCH

: The members of the Committee approve the thests of Vickie I. Hilgemann presented June 5, 1975.

Larry A. Steward, Chairman

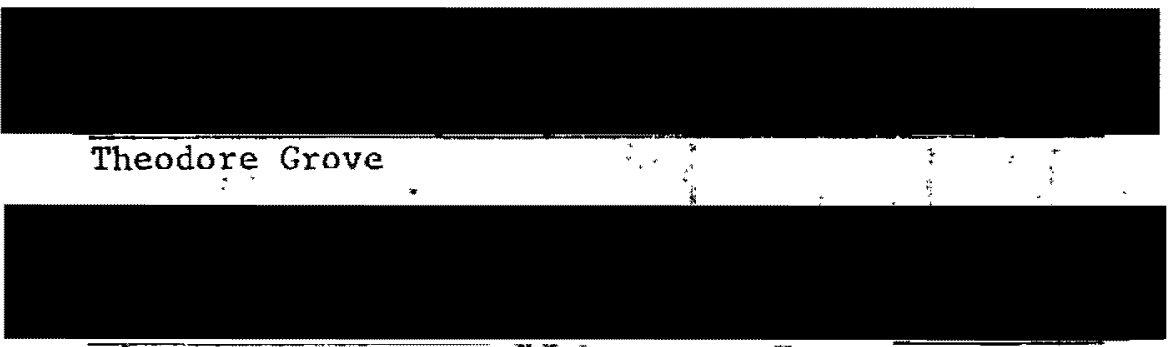

Rdbert W. Vogelsang $\mathscr{f}^{-}$, i

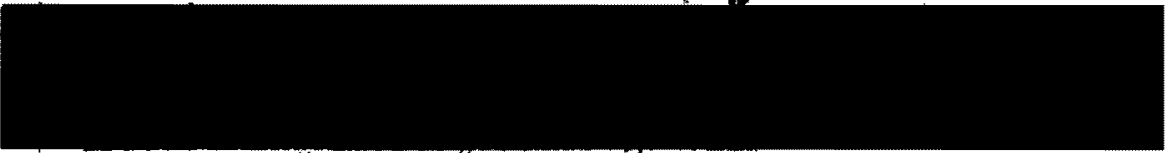

George V. Guy.

APPROVED:

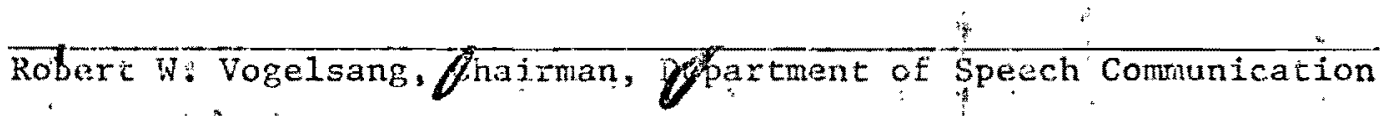
*. . .

Darid T.y Clark, Dean of Graduate Studies and Research 


\section{ACKNOWLEDGEMENTS}

A special thanks to Dave Gillette who aid the programming for this project. Also, many thanks to Genieve Windsor for all the help she gave in putting this paper into proper form. 
TASILE OF CONTENTIS

Page

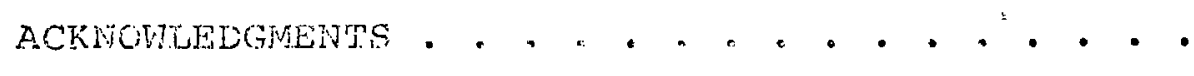

IIST OF TABLES. • • • . . • . . • • • • • •

vi.

CHAPTER

I INTRODUCTION • . . . . . . . . . . . .

II REVIET OF IITERATURE . . . . . . . .

III PROBLEMS AND PRCCEDTIRES. . . . . . . . 18

Genesis of the Problem. . . . . . 18

Rationale for the Approach... . . . 20

Assumptions of the Basic Course

Statement of the Problem

Hypotheses to be Tested . . . . . 22

Methods . . . . . . . . . . . 24

Introäuction

Rationale for the selection of the Procedure

Poplilation

Development of the Questionraire

Rationale for Categories

Design of Faculty Questicnnaire Design of Stuaent Questionnaire

Procedures

IV RESULTS. • • • . • • . . . . • •

Summary of Procedures . . . . .

38

Kendall Coefficient of concordance Spearman Rank Correlation Coefficjent Friednan Two-way Eralysis of Variance

Summary of Results. . • . . . . . .

V SUMMARY AND CONCLUSIONS. . . . . . .

Surmary . • . . . . . . . . . . . 
V SUMMARY AND CONCLUSIONS. . . . . . .

Suggestions for Fuxther study . : : 62

Limitations of the study. . . . . 64

A SELECTED BIBLIOGRAPII 。. . . . . . . . . 67

APPENDIX.................... . . . . . . 69 
TAELE

I Course Titles and Course Numbers for the Basjo Transfer Ciedit Public Spéaking Course. . . . . . . . . . . . . . .

II Number of Replies per student Questionnaire. . . . . . . . . . . . . .

II Communicative Situations Jisted By. Categories and Preference . . . . . . . . . . .

IV Statistics for kendally coefficient of Concordance For Internal Consistency of the student Questicmaire. . . . . . .

v statistics for Kendall coefficient of concordance For Internal Consistency of the raculty Questionnaire.. . . . . . . .

VI Statistics For spearman Rank Correllation Coefficient by Categories For the student Questionnaire. . . . . . . . . . .

VII Statistics For spearmar Rank Correlation Coefficient By Question For the Faculty Questionnaire. . . . . . . . . . .

VIII statistics For Friedman Two-Way Analysis Between Groups I, II, III and Group IV

IX Statistics For Friedman Two-way Enalysis Between Groups I, II, III and Group $\mathrm{I} . \mathrm{V} \cdot$ • • • • • • • • • • • • • • • • •

x Average Rankings By Categories of the Subgroups. . . . . . . . . . . .

XI Statistics For Spearman Rhos Between Subgroups of the Study. . . . . . . . : .

XII Significance Ievels for Spearman Rhos Between subgroups of the study . . . . . 
CHAPTER I

TNTRODUCTION

The contert of most introductory speech commication couxses in the past has been directed at improving students" skilis in oral communication. Recently investigators in the area of speech communication have challenged this "skilis" emphasis, thereby initiating some controversy concerning traditional pedagogical procedures. Should the basic course seek to improve tre stuaent's oral communication skills ass in the past? Should the basic course aim at developing the student's understanaing of the communication process? or should it attempt hoth?

Another issue that is rejevant as to the contents of the incroouctory spoech course is the emphasts in the course on puslic speaking andor interpersonal commication. prem sent practice in the classioar tends to madale tris issue. It is thit latter issue that is the concern of the present investigation.

Recent studies show that the majority of the colleges in the country still have an emphasis on pubijc ievel communication, $\dot{i}$ e., formal pubijo speeches to audiences (Review of the Literature). Meanwhile the rest of the aisoin. pline ife in the midst of accelerated revision: 
- - lory rela theories and traditional bedn agogios are bang aranged. The basic course, seemingly gutte objivious of the radical charges in tire form and subetance of the entire fiela

of speesh, contjnues as it always has.l

Most of the studjes juto content and methodology have been ane on the level of the four-year college. The problem concerning the best content and methodology to use is further compicated by the fact that a good share of those taking the introductory course will. be taking it at a two.. year collase or a comminity college. Twomear colleges have two prinary missions: one is concerned with giving stuäents the first two years of a four-year degree program. 2 A community college is designed in many cases to do the above, but oniy in addition to providing technical training in two-year terminal aggrees. 3 The Anerican Association of Junior colleges forecasts that by 1975, almost four million students will be enrolled in 1,22.5 two-year insticutions in the unjted states, eighty percent of which are community colleges. I The ciuestion then presents itself as to whether these students shovid be taught the same contert and with the same methodology ir. the introcuctory course. Indeed, are they the same type of student at a11?

It is the purpose of the present study, therefore, to investigate the needs of the commuitty college student, specifjcaliy the communty college student in the basic speech course. This will be iooked at from three views, these beirg: whit the student Eeels he neecs; what the 
instructor feels whot student needs: and what is being. taughe at the present tine in the basic speech course. The questions: will be answered via the use of a faculty and a student questionaire. The faculty questionaire will be designea to get information on what is presenty taught in the basic speech course and what the instructors feel students need. "want and get from this course. The student questionnaire asks what the students feel they need most to improve in the basic course (personal needs) and what they see as most important to do well in (societal needs). The answers to the two will then be compared' to determine results of this project.

In this thesis, there will be a chapter which shows an overview of the current literature in this area. Fnother chapter will describe the design of the study with a chapter to show interpretation ard results. Any conciusions warranted will then be presented. Such a study would be an. important contribution to the further understanding of what should be taught in the introductory speech communication course at this level. 
FOOTNOTES

1. Samuell R. Mehrley and James C. Backes. "The First Course in Speech: A Call for Revolution," Speech Teacher, XXI (September 1972), pp 205-210.

2. Furt R. Schmelier, President of oueensborough Commity College, "Speech and the Community College," The Journal of Western Speech, (Fal1, 1972), pp 5-7.

3. Ibid. p 5 .

4. Darlyn Wolvin and Andrew Wolvin, "The Speech Corrnunication Curriculum In the Community college," the Western Speech Journal, (Fal1, 1972), Pp 9-13. 


\section{CEAPTIS II}

\section{REVIEW OF TIE LTTERATURE}

This chapter wilj review the literature available pertinent to this study. rine worlss produced by Gibson, Gruner, Brooks, and Petriel; Deönon and Frandsen ${ }^{2}$; Friax ${ }^{3}$;

Kelley ${ }^{4}$ Markgraf ${ }^{5}$; and Prooks and platz ${ }^{6}$ together wili provide a comprehensive review of the literature relevant to this thesis.

The most recent and most comprehensive study into the content and methodology of the basic course was a study by Janes $W$. Gibson, Charles R. Gruner, Willjam D. Brooks, anc. Charles $R$. Petrie, Jr. ${ }^{7}$ This study centerea on the basic cout as taught in American colleges and vniversities in 1968. Whis did include the twomear colleges and conmunity coileges of the nation.

por "the furpose of the above study, the basic course was defined as:

What course exther reguired or recommended for a significant number of undergraduates; if is that speech course wilich the department either has or would jecommenas as being rem yuired for ali or most underyraduates if the coliege's adminiztrajoin asked it to name a course so required.

In Aprj] Jo6e, the investigators serit out a 52 iten questionnaire to 387 schools listed in the 1967-68 pinectony 
of the speech Association of Arerica as having an ärministrative officer in charge of speech. 9

By January 1969, 564 usable returns had been received from the colleges and universities (63.53 percent of the school) which constituted a representative sample of junior colleges and universities. 10

The questionnaire consisted of 52 items, most of which were amenable to categorical responses, with space provided for free responses to questions dealing with course objectives, syllabus materials, and major problems in teaching the course. 11 The data for the most part was tabulated to permit a comparison between junior colleges, colleges, and universities.

The question asked was, "What has been the basic emphasis of the course?" It was apparent that since the survey of Deämon and Frandsen of $1963-64^{12}$ a sizeable number of schools have shifted their declared emphasis from public speaking or fundamentals to communication or a multiple approach.

Nevertheless, the basic course in nearly 50 percent of the colleges, universities, and junior colleges continues to have a public speaking or fundamentals approach. Correspondingly, over three-fourths of the basic speech courses carry the title of public speaking or fundamentals. 13

The data further reported leads orie to suspect that whatever the declared emphasis or title of the basic course, the course content centers around public speaking. The topics deajt with in the basic course by most of the responaing schools are those related 
to public speakjng; informative ard persuasive spedking, supporting material, delivery, oullining, reasoning, andiense analysis, topic selection, listenting and motivation. In addition, with the exception of these topics, there is apparently little agreement about what should be taught in tre basic course. Relatively few courses deal specifically with such topics as ethics, the rhetorical criticisms, interviewing, and communication theory. The textbooks most frequently used in the basic courses also appear to emphasize public speaking. 14

"In some respects the emphasis on public speaking and fundamentals is both denied and afrirmed by the course objectives which were reported." 15

Finally, the study showed that over fifty percent of the colleges, universities, and junior colleges reporting were satisfied with the course as it was presently taught. 16

Since most schools indicated that the faculty was satisfied with the course structure, one must conclude that this orientation reflects the inclination of most basic course instructors. 17

A very similar study was done a few years prior to the above. This one was by Donald N. Dedmon and Kenneth D. Frandsen. The study was begun in late January 1963. A questionnaire vas mailed to 925 colleges and universities listed in the 1962 edition of the SAA IIRECTORY. The data was compiled from the 406 complete returns. 18 The results showed that

- 54.68 percent of all respondents, including those who require a first course plus those who do not, call their course 'practical public speaking'. 19

Dedmon and Frandsen concluded the communication theory 
courses had made only miror inroads into the popularity of the public speaking as a required first course in speech in colleges and universities in the U. S. $20^{\circ}$

Another study into the methods and trends in the jurior college basic speech course by Don Friar, instructor in Speech at Imerican River Coljege, Sacremento, California, investigated the basic course as taught in the western Speecin Association area. 21 In October 1966, questionnaires were sent to the offices of the presidents of all junior colleges in the fourteen western states listed in the American Junior college Association Directory. A return of ovex ninety percert was received, from which a composite list of 458 instructors currently teaching the basic course was obtained. 22

In Apri]. 1967, questionnaires were; sent" out that. were concerned with class size, number and types of speeches, evaluation and grading of speeches, use of special facilities, innovative attempts, and general trends, practices, and techniques. 23 or. the 458 questionnaires; one hunared and eightys seven were retirned, a sampling of $40 z .24$ a number of those answering indicated that their rieply represented the methods and trends of the entire speech department of theix school. The replies represented a isampling of $76 \%$ of the 2.25 schools polled. 25

The results indicated that $49 \%$ of the schools had students give five to seven speeshes during ithe course and that 
$38 \%$ said they had eight to ten speakirg assignments.26 The speeches considered most important as assignments were: the speech to inform, the speech to persuade and the speech to demonstrate. Friar concludes, "The typical junior college speech course, then, emerged as one which emphasized public speaking".27 Judging from the available data, approxinately $60 \%$ of class time was devoted to performance and nearly $20 \%$ to speech criticism. 28 Friar states,

Although a variety of pedagogical approaches was in evidence, we found the primary aim of the junior college first course was to develop in the student a general facility in the basic techniques of speech preparation and delivery. Iistening improvement, critical thought, rem search and organizations skilis, anä allied goals were seen as by-products of this overall design of most class offerings. Any specific aims of the irstructors seemed to fall between making the course academically respectable for the transfer student and immediately functional for the terminal student. 29

A more recent study in the community college basic speech course was conducted by William kelly, in an article entitled "Speech Instruction in Cailfornia Community Colleges" pubilished in septenber 1970 in the Speech Teacher. 30

This is the only study found that deals exclusively with the communty college speech classroom. The purpose of the study wäs (1) to ảiscover speech programs policies and procedures; (2) to draw certajn comparisons between collegea grouped as to size; and (3) to study how teachers structure and teach the basic transfer speech course. $3 i$ Interestingly the term "basic transfer speen coursc" was defined as the 
credit transfer speech course in public speaking, bhich, in Californta, is the first course taken by most students seeking a baccilaureate degree. 32 According to Mr. Kelley, this course, with varying titles, is the one most often transferred for speech aredit when students leave the junior college for the senior college or university.33

Duxing the spring of 1969, seventy-ight California public communty coljeges were visited, representing a sample of $92 \%$ of this type of institution in the state. 34

The methodology included personal interviews with aciminjstratoxs and teachers, a set pattern of interview questions, class visitations involving observations of teachers and students, and collections" of printed"instructional nat.erial, course outines, and coslege catalogs. 35

Conclusions of this study include the finding that the only course being taught at most colleges was the piblic speaking course for university transfer. 36 The following chart stmmarizes this conclusion: 


\section{TABLE I}

COURSE TITLES AND COURSE NUMPERS:FOR THE

BASIC TRANSFER CREDIT PUBIIIC

SPEAKING COURSE

\begin{tabular}{|c|c|c|c|}
\hline Course Titles & $\begin{array}{l}\text { Freq. of } \\
\text { Tities }\end{array}$ & $\begin{array}{l}\text { Course } \\
\text { Numbers } \\
\end{array}$ & $\begin{array}{l}\text { Freq. of } \\
\text { Numbers }\end{array}$ \\
\hline $\begin{array}{l}\text { Public speaking } \\
\text { Fundamentals of }\end{array}$ & 22 & $\underline{\mathrm{I} A}$ & 32 \\
\hline $\begin{array}{l}\text { Speech (ox) } \\
\text { Speech }\end{array}$ & . & . & \\
\hline Fundamentals & 14 & 1 & 26 \\
\hline $\begin{aligned} \text { Elenents of } \\
\text { Speech (or) }\end{aligned}$ & & & \\
\hline $\begin{array}{l}\text { Speech Elements } \\
\text { oral. }\end{array}$ & 10 & 3 & 3 \\
\hline Cominunication & 6 & 45 & 3 \\
\hline Speech & 6 & 120 & 3 \\
\hline Public Address & 5 & $2 \mathrm{~A}$ & 3 \\
\hline 11 other titles & 17 & 7 others & 10 \\
\hline Totals & 80 & & 80 \\
\hline
\end{tabular}

Note: Although there were 78 colleges in the sample, two colleges had an option of two basic speaking courses for transfer credit. 37

All sizes of colleges tended to enroll more than twice as many students in the basic universitypublic speaking course than in all other courses combined. 38 .

The type of speeches most commonly assigned were exposition, persuasion, demonstration, impronptu, discussion, and such.39 The number of speeches ranged from two to thirteen withia mean of 8.9 .40 Kelley concluded by listing what he felt were the trends of the speech course in the community college. Among these trends were the concepts that students learn to communicate by getting them up on their feet.41 
Another tiund is that the major part of a student's grade in the basio speech course is based mom pepared speches. 42 Bruce Markgraf, Aesociatte Frofessor and chatiman of the departmont of Speech at Derison miversity, ir an article on traditional speech pedagogion methods says that the most beneficial possible basic course vould be one that allows a student to give a few longer speeches during a semester. 43 His rationale includes the comment,

My conception of the first course in speech is one of public speaking, explanatory and persuasive, rather than one of fundarientals. I prefer concentration to a surface voyage through various types of speaking." I hold that individuals are most 1ikely to enploy extemporaneous anä impromptu speaking in daily situations. 44

it is necossary to also inention a study by william $D$. Brooks and Sarah M. Platz in this review of the iterature. Broolis and platz completed a reseaxch program into "The Effects of Speech Traintrg Uron Self-Concept As a Communicator." 45 selewconcept is defined as: "The manner in which a student perceives hipself as a conmunicator." 46 Brooks and platz's study asked the question of whether the basic speech course effected the person's concept of thenselves as a continicatox. Phrough the use of a o-Sort testing instrument, they determined that the basic speech course did not protuce betier sej. f.concepts as communications. 47 As a matter of fact, about one-fourth of the experimental group made aramatic shifts torarcs a lower self-concept. 48 They concluated that: 
It may be that the students who made negative changes in how they perceived themselves as comunicators are a population different from those who improved their self-concept, and it inay be that they need a different speech experience. 49

Along this line of research, James McCroskey of Michigan State University, investigated the effect of the basic speech course on students' attitudes towards themselves as speakers. 50 Eight hundred and twenty-three students enrolled in fifty sections of the basic speech course at Pennsylvania state University were measured via a semantic differential scale for their concept of themselves as speakers.51 the major finding of this study can be summarized,

There is a diffexence between students' attitudes toward themselves as speakers at the begiming of a basic speech course and their attjtude toward thernselves as speakers at the end of the course. 52

McCroskey goes on to conclude that while there may be increased confidence in a stuāent's speaking ability, this does not necessarily mean that the student will improve his speaking ability in the basic speech course. 53

As can be seen in overview; the Gibson, Gruner, Brooks and Petrie study affirms that public speaking is the primary emphasis of most college speech courses as did the earlier research by Dedmon and Frandsen. Don Friar did a study into junjor college in the western states as to trends of the basic course. He again found basically a speaking approach to the basic course. William Kelley in his study found basically the same in the california comminity college 
system. However, research by Wiliian Brooks and Sarah Platz showed that this kind of course does not necessarily meet the needs of all students. Indeed, at times it may be harmful to the self-concept of some. Lastly, James McCroskey concluded that these courses may increase some students' confidence in speaking, but not improve their speaking ability.

of ail the studies mentioned in this review of the literature in the area, there are none that involved the basic speech course of the community college which is for the twoyear terninating vocational/technical student. 


\section{FOOTNOTES}

1. James Gibson, Charles Gruner, William Brooks, and Charles Petrie, Jr., "The First Course in Speech: A Survey of U.S. Colleges and Universities," The Speech Teacher, (January, 1970), pp 1.3-20.

2. Donald Dedmon and Kenneth Frandsen, "The Required First Course in Speech: A Survey," The Speech Teacher, (January, 1964), pp 32-39.

3. Don Friar, "Methods and Trends in the Junior College Basic Speech Course," Westerri Speech Journal, (Spring, 1970), pp 148-153.

4. William Kelley, "Speech Instruction in California Community Colleges," The Speech Teacher, (September, 1970), pp 211-223.

5. Bruce Markgraf, "The First Course in Speech," Western Speech Journal, (Spring, 1969), pp 92-100.

6. William Brooks and Sarah Platz, "The Effects of Speech Training Upon Self-Concept as a Communication," The Speech Teacher, (January, 1968), pp 44-49.

7. Gibson, op. cit., p. 13

8. Ibid, p. 13

9. Ibid, p. 13

10. Ibid, p. 14

11. Ibid, p. 14

12. Dedmon, op. cit., p. 31

13. Gibson, op. cit., p. 15

14. Ibiä, p. 15

15. Ibid, p, 15

16. I.bid, p. 16

17. Ibid, p. 20

18. Dedmón, op. cit., p. 31

19. Ibid, p. 33 
20. Ibid, p. 37

21. Friar, op. cit., p. 148

22. Ibid, p. 149

23. Ibid, p. 149

24. Ibid, p. 149

25. Ibid, p. 149

26. Ibid, p. 150

27. Ibid, p. 152

28. Ibid, p. 152

29. Ibid, p. 152

30." Kelley, op. cit., p. 211

31. Ibid, p. 211

32. Ibid, p. 211

33. Ibid, p. 211

34. Ibid, p. 212

35. Ibid, p. 212

36. Ibid, p. 215

37. Ibid, p. 217

38. Ibid, p. 216

39. Ibid, p. 218

40. Ibid, p. 218

41. Ibid, p. 223

42. Ibid, p. 223

43. Markgraf, op. cit., p. 98

44. Ibid, p. 99

45. Brooks, op. cit., p. 44 
46. Ibid, p. 45

47. Ibid, p. 46

48. Ibia, p. 47

49. Ibid, p. 47

50. James McCroskey, "The Effect of the Basic Speech Course on Student's Attitudes," The Speech Teacher, (March, 1967), pp 115-117.

51. Ibid, p. 115

52. Ibid, p. 116

53. Ibid, p. 117 
CHAPTER III

PROBLERS AND PROCEDURES

\section{GENESIS OF THE PROBLEM}

The impetus for the present study was the realization that no studies have been attempted to determine the validity of the content and methodology used in the basic speech course for the community college level student who is in a non-transfer program. Indeed, until recently, the transfer introductiory speech course at the junior college level was not inciuded in studies concerning this area.

The" studies by Gibson, Gruner, Brooks and Petrie ${ }^{1}$ and by Dedmon and. Frandsen ${ }^{2}$ are geared for the most part to determine. what is taught in the four-year colleges of the nation. More recant studies by Friar ${ }^{3}$ and Kelley ${ }^{4}$ have focuseả on the junior colleges anả community colleges but do not inclucie the non-transfer student.

The findings of all the above mentioned studies center on the content and class situations of the basic introductory speech course. The assumption that all seem to indicate is that the basic course for the most part is one with a public speaking emphasis. Yet, thère are few findings that support the rotion that this is the best"method of helping students to jmprove in their abilities tộ communicate with 
others. Many have said that they do not feel that an oral communication emphasis is what the students need most in the introductiry speech course; but neither do available facts. support the validity of this statement.

A second reason exists for the study at hand. A review of the literature reveals that the information concerning the content and methodology of the basic speech course was all obtained from speech teachers and some from administrators of the various colleges. No-studies, other than the one by Brooks and Platz ${ }^{5}$ dealing with the self-concept of the communicators in a speech classroom, asked the students how valid they felt the content and methodology was that is currently being taught in the speech classroom. An answer from students to the above question is, indeed, important if one is to try to determine with any accuracy the needs of the student in the basic speech course.

It seems then, the only way to determine whether or not the community college non-transfer, as well as transfer student, is getting what he feels he needs in the basic speech course is to question him, as well as the instructors, who teach him at this level. Perhaps, a combination of the two replies will be an indication of the needs of these students and if they are currently being/met. 


\section{RATTONALE FOR THE RPPROACH}

\section{Assumptions of the Basic Speech Course}

The following is a clarification of the investigator's assumptions concerning the basic non-transfer speech course and the assumptions concerning the measuring devices used in this study.

Probably the primary assumption made concerning the introductory speech course was that it is a class that emphasizes the public speaking aspect of communication in the past in colleges. This assumption is upheld by the research in this study and seems to be one held by both administrators and faculty of the various community colleges in the oregon system. Along with this assumption there seems to be a preliminary assumption on the part of the schools that students will learn to become more effective communicators via the public speaking route. Namely, that by getting up in front of a group of people there will occur an increased ability to communicate on the part of the student. However, up to this point there seems to be very iittle, if any support to this contention. Indeed, this basic assumption on the part of the administrators and teachers supposes that this is the need area of the community college students. yet, again, there seems, to be no research that supports this supposition, especially no studies done in which students were asked what their needs were.

A second assumption that seems to be implicit in the 
content and methodology of the current basic speech course is that all students are able to learn when placed in front of a group of people for the purpose of giving a speech. A.lso, it supposes that all people can learn by the same methods of teaching. It would seem that, indeed, the needs of students do vary and consideration to this must be given. More likely it would be assumed that the communicative needs of the community college student do vary. Perhaps, the public speaking "angle" is not the weak point to many community college students. Many would certainly not see this as the area of communications that they feel is the most important for them to do well.

One last question that was pondered, but no research is available to provide any answer, is to what extent is a community college student different from, or similar to, a four-year college student in his communicative needs? Likewise, is thece a difference between the (non-transfer) vocational/technical community college student's communicative needs and the communicative needs of the transfer junior college students, that is, one who intends to go on to a four-year institution? Also, it must be asked what affect a prior speech course taken might have had on a given student.

Statement of The Problem

The problem to be investigated is as follows: To what extent are underlying assumptions of the basic speech communication courses at the community college level as seen 
by the instructors simjlar to, or difierent from, the self-

reported needs in communication training of the community

college student?

The specific areas to be researched are:

(1) What are the underlying assumptions of the basic speech communication courses at the community college level as seen by instructors?

(2) What are the felt-needs with regard to speech communication training of the community college student as reported by said students?

(3) To what extent are the basic assumptions and the self-reported needs of the students congruent with each other?

\section{HYPOTHESES TO BE TESTED}

This entire study, for the most part, centers on one particular hypothesis, that being:

HYPOTHESIS I: - There is a positive correlation between the basic assumptions of the introductory speech communication course as seen by the speech communication instructor and the student-felt needs in this course.

The basic underlying assumptions of the basic speech communication course were determined by the faculty questionnaires that were sent to all the oregon community college speech communication teachers.

students were asked to fill out a questionnaire as to what their basic needs were in communications. This questionnaire was divided into two areas for these students: First, they were asked to rank communicative situations in which they felt it was most important for them to do well and 
secondly, what they felt they needed most improvement in. From this evolves the following secondary hypothesis for this study:

HYPOTHESIS II: There is a positive correlation between what students feel they need to improve in communicativewise in the introductory speech communication course and what they feel is mosid important for them to do well in comrnunicativewise.

In the faculty questionnaire, the speech communication instructors were asked the following three questions: What did they feel the students' needs were in communication situations? (2) What did they feel that students wanted from the introductory speech communication course? What did they feel that students got from the introductory speech communication course? The answers to these questions seem to bring forth the following secondary hypotheses: HYPOTHESIS III: There is a high degree of consistency between what the speech communication faculty feels are students' needs inthe communication area in the introductory speech communication course and what they perceive that students get from the introductory speech communication course.

HYPOTHESIS IV:
There is a high degree of consistency between what the speech communication faculty feels that students' needs are in communication and how the faculty perceive what students want to do to improve their communicative needs.:

HYPOTHESIS V: There is a high degree of consistency between what the speech 
communication faculty feels studerits want to do to improve their comminicative needs and what studerits get from the course as. seen by instructors.

It is not supposed that the findings of this study will be sufficient to give definite answers to all of these hypotheses, but these were the questions that were in mind in planning this particuiar research project.

\section{METHODS}

Introduction

Student-felt needs in the basic speech communication course can oniy be brought to light through a process involving themselves. This study, in part, focused on devising an instrument that would gleen information from the community college students about their needs in the basic course without test bias. A questionnaire was developed that allowed students to rank, communication situations to get this information.

To discover the current speech communication pedagogy and teacher-felt-needs, the speech instructors of the community colleges, were also asked to fill out a questionnaire. It was decided that this would be a way to discover the current content and methodology used in the community college basic speech communication course. Also, the questionnaire was intended to get a glimpse of student needs as seen by the speech instructors in the community college. 
Rationale For The Selection of the Procedures

Two limiting factors, the lack of ability to handle the vast numbers of students availabje and the degree of administrator reliability, served as the basis for the rationale for the procedures selected.

The rationale for the number and composition of the sample of students in the basic speech courses in the community colleges was based on several things. First, it was not feasible to handle the number of people in the entire population of the community college students in the basic speech course. Secondly, it was not possible for the author to interview all students and faculty to ask which communicative situations were important to them? Therefore, a more objective measuring device was necessary. As a result of this finding, a ranking scale questionnaire was used for both faculty and students. The use of a numerical-oriented questionnaire allowed for a statistical tabulation with the use of a computer. This made it possible for the author to take a larger sample of the total population for this study.

Population

The student population consisted of a sample of twenty or more students selected randomly from three of the thirteen comminity colleges in oregon. The students were those enrolled in the non-transfer basic speech course, with the exception of one small sub-sample of transfer students. The entire population of speech communication faculty 
in the Oregon community colleges were questioned on their views of student communication needs. This population consisted of forty-four speech communication instructors.

Development of The Questionnaires

Rationale for Categories. A set of tentative categories were established by the author for the sake of accommodating the development of the student and faculty questionnaires. The categories are as follows:

1. Public Level - On this level, meaningful communication in a structured group situation is needed.

2. Adult/Parental Level - on this level, meaningful communication with parents or other influential adult outside of the family is needed.

3. Authority Leve - On this level, meaningful communication with any authority figure, such as an employer, a teacher, or others, is needed.

4. Social Level - On this level, meaningful communication with peers, either on the interpersonal or group situation in a social context, is needed.

5. Utility Level - On this level, meaningful conmunication with any person about daily need situations such as giving directions or instructions, small talk, and other, is needed.

These categories appeared to be a workable division of the possible communication situations in which a student might become involved.

To determine if these categories would cover all the communications situations of the students in the community college basic speech communication course, a pre-test information device was used. Eighty students at Chemeketa Comminity coliege, in Salem, Oregon, in both the transfer 
and non-transfer basic speech courses offered in the fall

of 1972, were asked to respond to the follow guestion:

Rank in order of difficulty three frequently occuring different opportunities to communicate where you would like to be able to communicate effectively but find it difficult. Identify briefly the relationship of the person(s) (position, etc.) and the nature of the situation (reason or communicating) for each item ranked.

This question was worded in such a way as to attempt to avoid test bias. The only directions given were the written ones that follow:

I need your help! I'm doing a study on student needs in the area of speech communication training. Hopefully, this will end in benefits for speech students. Will you please answer the question on the next sheet as honestly and completely as possible. You need not put your name on the paper; nor will the answers be used in any way for evaluation in this class.

The administrators of this pre-test were advised to give no further directions. The results from students who did not follow the directions properly were discarded, leaving sixty-five completed questionnaires to analyze.

The results of this preliminary survey of students' communicative situations for the most part verified the categories selected, except for the minor revisions. The

final categories used in the questionnaire were:

1. Public Level - To what extent do students recognize need in the use of meaningful communj.cation in a structured group situation?

2. Close Friends - Family - To what extent do students recognize need in the use of mean- 
ingful communication with family or other influential persons outside of the home?

3. Superior-Subordinate Level - To what extent do students recognize need in the use of meaningful communication with any authority figure such as an employer, a teacher, or others?

4. Social Level - To what extent do students recognize need in the use of meaningful communication with peers either on the interpersonal or group sitaution in a social context?

5. Utility Level - To what extent do students recognize need in the use of meaningful communication with any person about daily need situations, such as giving directions or instructions to others?

The only areas the prior set of categories did not meet, according to the students, appear to be in these communicative situations:

(1) Those communicative situations involving a person's most intimate friends were not adequately covered. This communication was too personal to be considered on the social level. Therefore, it seemed to fit best in the familial area. Consequently, the Adult/Parental level of communication was changed to meet these needs to the close Friends - Family level.

(2) Those situations involving difficulty in communication in a working situation between an employer and an employee were not covered adequately. The concern was expressed by students with the communication going in both directions, not just from employer to employee. Therefore, it was necessary to change the Superior-Subordinate level.

Not all students listed three communicative situations in the pre-test questionnaire. It seems that perhaps time may have been a factor. The number of responses per questionnaire were as follows: 
TABLE II

NUMBER OF REPLIES PER STUDENT:

PRE-TEST QUESTIONNAIRE

\begin{tabular}{|c|c|c|}
\hline $\begin{array}{c}\text { No. of Communication } \\
\text { situations listed per } \\
\text { questionnaire }\end{array}$ & $\begin{array}{c}\text { No of questionnaire } \\
\text { filled out this way }\end{array}$ & $\begin{array}{c}\text { No of communi- } \\
\text { cation situations } \\
\text { listed in total }\end{array}$ \\
\hline 1 & 15 & 15 \\
\hline 2 & 26 & 52 \\
\hline 3 & 24 & 72 \\
\hline Total & 65 & 139 \\
\hline
\end{tabular}

This table demonstrated what specific categories each student felt was most difficult for him to communicate effectively. He was asked to give these in order of priority. The responses in the 65 questionnaires were divided in the following manner: 
TABLE III

COMMUNICATIVE SITUATIONS LISTED

BY CATEGORIES AND PREFERENCE

IN PRE-TEST QUESTIONNAIRE

\begin{tabular}{|l|c|c|c|c|}
\hline Categories & $\begin{array}{c}\text { lst } \\
\text { Choice }\end{array}$ & $\begin{array}{c}\text { 2nd } \\
\text { Choice }\end{array}$ & $\begin{array}{c}\text { 3rd } \\
\text { Choice }\end{array}$ & Total \\
\hline Social & 24 & 18 & 11 & 53 \\
\hline Public & 18 & 11 & 5 & 34 \\
\hline Friend - Family & 8 & 8 & 2 & 18 \\
\hline Superior - Subordinate & 15 & 8 & 4 & 27 \\
\hline Utility & 4 & 2 & 1 & 7 \\
\hline TOTAL & 69 & 47 & 23 & 139 \\
\hline
\end{tabular}

The communicative situations used in the final questionnaires, both student and faculty, were drawn from this preliminary survey.

Design of Faculty Questionnaire. In designing the faculty questionnaire, it was most important to come up with a testing device that was concise yet simple to complete. It appears that there is a direct relationship between the amount of time a faculty member needs to spend filling out a questionnaire and the number of questionnaires returned. The questionnaire was Iimited to two pages with eight questions that were, for the most part, a simple "circle the correct 
answer" or "fill in a number". A self-adaresșed envelope was included for the convenience of the speech communication faculty qüestioned.

simplifying the testing device as to inguire into the basic assumptions of present introductory speech courses, created many semantical problems. Terminology was selected to eliminate test bias as much às possible.

It was also decided that a cover letter (see appendix) would be needed to enhance the amount of responses to this questionnaire. This questionnaire needed to be as nonthreatening as possible." This letter stated that the questionnaire was only being used to determine the current methodology in the introductory speech communication course in the oregon community colleges and not as an evaluation tool. In addition to this; they were told that feedback was needed from all community colleges in order for the author to complete her research study. It was assumed that this was enough to allay fear of reprisal for any answers. However, some bias in faculty answers attributed to a personal need of faculty to enhance their self-images is inevitable. Accordingly, the interpretation of resulting data should be conservative.

of the eight questions contained in the questionnaire, the first four dealt with institutional policies concerning the introductory speech communication course, namely, whether the course was transfer, non-transfer, or both. They were 
asked if it was required for graduation; if and how its contents were governed by school policy, and what emphasis the text had.

The second half of the questionnaire attempted to get at sutdent needs as viewed by the faculty. They were asked to rank five communication situations in terms of priorities, as to, what they felt students wanted in the basic course; what they felt students needed in this course; and what they felt students got from this course. Lastly, they were asked if they were satisfied with the course as taught - or how they would like to change it. (See Faculty Questionnaire in appendix.)

Design of student Questionnaire. In designing the student questionnaire, it was also important to develop a testing device that was relatively short and easy to fill out. It needed to be one that was understandable in both directions to the students and in the communicative situations with which they had to deal. It was, with this in mind, decided that a ranking scale of communicative situations be the most conducive way to elicit student-felt needs with some indication as to priorities. Therefore, the questionnaire consists of four pages, each with sixteen ranking sets of five communicative situations each. These communicative situations were determined through a pre-test questioning of students to determine a set of workable categories.

Like the faculty questionnaire, there were many semantic 
oriented considerations that had to be made when developing this questionnaire. The communicative situations used were taken from the pre-test sample and the wording was only slightly altered to take out student biases from these. Much thought was given to the exact wording of each of the situations listed. For example, the words like "father, mother, and parents" were buffered for emotional reactions by adding in each of the communicative situations using these words the additional words "or close family friend." It was, also, attempted to word this questionnaire in such a way that a student of eighteen and thirty-five would both find the communicative situations applicable to them since the student populations of the community colleges do vary greatly in age. The questionnaire was accompanied by a set of directions and a short explanation of purpose to the students filling out the questionnaire. The explanation consisted of the following:

TO STUDENTS: Please fill out this questionnaire as completely and honestly as possible. It is part of a study being done to determine what students want and need from their introductory

- speech courses. Your help on this project is greatly appreciated. Ask the administrator if you have any questions regarding directions.

This explanation was given in an attempt to allay any student fears of reprisal for filling out this testing device. Students were, also, allowed to remain anonymous.

The directions to the questionnaire were devised to be as simple, sut as complete, as possible. It was hoped that they would be sufficient for the students so that they did 
not have to question the test administrator about directions. This was done in order to reduce introduction of bias by the administrator. The test administrators were cautioned not to give any personal interpretations of the meaning of words or situations used in the ranking situations." (See appendix for a copy of student questionnaire with directions.)

The questionnaire itself consisted of two parts, with eight ranking situations in éach. The first part of the questionnaire asked the students to rank communicative situations as.they judged were most important for them to do well in. The key in this was for the student's to judge what they felt: would enhance them the most in sociấl or work situations, depending on which was of the highest prifority to them.

The second part of the questionnaire asked the students to rank communicative situations in accordance with what they felt the most need to improve. In this section students were to judge their areas of need for improvement. This combination of the result of both parts should point out what students feel they need in the introductory speech course.

\section{Procedures}

Student questionnaires were distributed to test administrators at Chemeketa Community. College, Blue Mountain Community College in Pendleton, Oregon, and "Clackamas Community College in oregon City, oregon, with a set of directions prior to the beginning of the winter term of 1973. Administrators were warned to make no further comments to students 
other than the written directions on the top of the student questionnaire.

The "student questionnaire was given to all first year students at Chemeketa comminity college ếntering the class called Communication skills 1.104. This"class is the introductory speech communication course taken by the non-transfer community college students at this particular school. In total there were 184 student questionnaires filled out at Chemeketa Community college in the non-transfer program. In addition, there were small samples of student responses taken at two other community colleges offering a similar introductory speech course. These school's were chosen randomly. There was a sample of 32 students taken from clackamas Community college. Likewise, a sample of 30 students was taken from Blue Mountain College. At both colleges, the course was labeled the introductory speech course to be taken by the non-transfer student. A small sample was also taken from the introductory speech course (Speech 111) on the transfer level at Chemeketa Community College. This sample included thirty-five questionnaires. These were taken for use of comparison, with the non-transfer 'students' responses. The total sample taken at the three community colleges was 281 .

All questionnaires were given to students in the basic speech courses at these schools on the first day of the term. This was done to circumvent the possibility of teacher influence on the students' answers to the questionnaire. These 
questionnaires were then collected by the author for statistical tabulation.

The faculty questionnaires with a çover letter of explanation were sent to 44 speech communication instructors at the community colleges in oregon. The letters were sent approximately two weeks into the winter term of 1973. The population was determined through the use of the oregon Community College Association Handbook ${ }^{6}$ äs teaching communications and/or speech courses in the thirteen community colleges. An'swers were received from 28 , speech instructors representing 12 of the 13 community colleges in oregon. The questionnaires were then statistically tabulated with the results shown in the next chapter. 
37

FOOTNOTES

1. Gibson, Op. Cit., pp 13-20.

2. Dedmon, Op. Cit., pp 32-39

3. Friar, op. Cit., pp 148-153

4. Kelley, Op. Cit., pp 211-223.

5. Brooks; Op. Cit., pp 44-49

6. Oregon Community College Association, Director to Personnet in Oregon Community Colleges, 1973-74, Salem, Oregon. 
CHAPTER IV

RESULTS

I. SUMMARY OF PROCEDURES

It is the purpose of this chapter to describe the data proaucing procedures used in this study and their results. The following questions had to be asked of the data to answer the five hypotheses already stated in the last chapter:

1. Was the testing device reliable? (Internal cọnsistency/Reliability)

2. Do the parts of each questionnaire have any degree of association with another part of that questionnaire? (Student Paìt I vs. Student Part II') (Faculty Perceptions Student Needs vs. Student Want's, Student Needs vs. Student Gets, Student Wants vis. Student Gets)

3. Are the responses of aifferent groups of students associated with one another? (Transfer siudents v.s. Non-transfer Students) (Chêmeketa vs. Blue Mt., Blue Mt. vs. Clackamas, Chemekeța vs. Clackamás)

4. Do the various parts of the two questionnaires together have any degree of association with one another? (Matrix of correlations among the data sets)

First as a test reliability measure; thirteen Kendall

Coefficient of Concordances $(w)^{l}$ were computed to assess interitem reliability within both the faculty and students' questionnaires for each of the five scales. The of association among the variable. In addition, 
two Kendall W's were computed to ascertain possible consistency across all scores in data for each of the scales in the student questionnaire. (Answer to question 1 above.)

Secoñly, eight Spearman Rank Correlation Coefficient $\left(r_{s}\right)^{2}$ were computed to measure the degree of association of variables in two ordered series. Another Spearman was applied between the sections of the student questionnaire to determine if there was a correlation between all students' answers to Part I and Part II. (Answer to question 2.) Three more Spearman Rhos were computed to assess correlation between the three sections in the faculty questionnaire.

A procedure was needed for comparing the answers to the questionnaire given by the various groups who were given the test instrument. The Friedman Two-Way Analysis ${ }^{3}$ of Variance was applied to data from Groups I, II, III, and IV in the student questionnaire. A second Friedman was done to compare vocational groups (I, II, III) to transfer group (IV). (Answer to question 3.)

The last set of statistical procedures consisted of Spearman Rhos between the two parts of the student questionnaire and the three parts of the faculty questionnaire to see if there were any correlations between all parts of both test instruments. This was done only after the reliability of each test instrument was determined separately. (Answer to question 4. )

The section below will describe the procedure involved in using the above statistical design. 
The Kendall Coefficient of Concordance

The Kendall Coefficient of concordance was used to express the degree of association among variables. In both the student and faculty questionnaires, there were five categories to be ranked by respondents. The observed ranks were then cast in a $\mathrm{K} \times \mathrm{N}$ table. In our case with an $\mathrm{N}$ no larger than seven, the formula: $x^{2}=K(N-1) w .4$ A high significant valiue of $w$ may be interpreted as meaning that the persons ranking are applying essentially the same standard in ranking the objects under study. 5

In applying the first set of ten Kendalls, the question was asked to what extent do the items in the student questionnaire present a stable response. A null hypothesis was established that indicated that the $\mathrm{K}$ rankings were unrelated: to each other. An alpha level of .10 was established. The following results were recorded: 
Table IV

KENDALI COEFFICIENT OF CONCORDANCE FOR INTERNAL CONS.ISTENCY OF THE STUDENT QUESTIONNA.IRE

\begin{tabular}{|c|c|c|c|c|}
\hline Group & Part I & Significance & Part II & Significance \\
\hline I & .47 & .01 & .84 & .001 \\
\hline II & .51 & .01 & .83 & .001 \\
\hline III & .42 & .01 & .82 & .001 \\
\hline IV & .56 & .01 & .88 & .001 \\
\hline Total & .46 & .01 & .84 & .001 \\
\hline
\end{tabular}

From these statistics, it appears that the null-hypothesis can be rejected. It seems that there is a high degree of inter-item reliability. This consistency shown in the parts of the student questionnaire would allow one to predict the answers to the eight questions in each part. Thus, it would seem that this questionnaire could be referred to as an eight-item scale.

One thing to be noted, however, is that there seems to be more uniformity in what students feel they need to improve in communicativewise (Part II) than what he deem that society thinks he needs to be good in communicativewise (Part I).

A second set of three Kendall's were used in determining consistency in the answers to the three questions (dimensions) in the faculty questionnaire. A null hypothesis was posited that the $K$ rankings were unrelated to each other and an alpha 
level of .05 was set. Using the same procedures as before, the following statistics computed:

\section{Table V}

KENDALL COEFFICIENT OF CONCORDANCE FOR INTERNAL CONSISTENCY OF THE FACULTY QUESTIONNAIRE

\begin{tabular}{|c|c|c|}
\hline $\begin{array}{c}\text { Dimensions: } \\
\text { Questions Asked }\end{array}$ & Kendall w & Significance \\
\hline $\begin{array}{c}\# 1 \\
\text { Student Needs }\end{array}$ & .0897 & .05 \\
\hline $\begin{array}{c}\# 2 \\
\text { Student Wants }\end{array}$ & .0992 & .05 \\
\hline $\begin{array}{r}\# \text { 3 } \\
\text { Student Gets }\end{array}$ & .1525 & .01 \\
\hline
\end{tabular}

From these results, the null hypothesis can be rejected. The consistency in answers of the faculty members permits this to be considered three scales.

The third set of 2 Kendals were applied to determine to what extent do all the subjects' answers to the questionnaire intercorrelate with each other throughout the student questionnaire. There were 281 students who filled out the text instrument. A null hypothesis was established that indicated that the $\mathrm{K}$ rankings were unrelated to each other. An alpha level of .10 was set. Using the procedures listed earlier in this chapter, the following results were obtained:

Part I Tot. .1737 .01

From these results, it can be assumed that the null hypothesis 
may be rejected. Also, it may be assumed that there is consistency in the answers to the questionnaire among; the persons filling out the student questionnaire.

Spearman Rank Correlation Coefficient

The second statistical procedure applied was the spearman Rank Correlation Coefficient: $r_{S}$. This statistical procedure was applied to assess correlation between the various parts of each questionnaire. The student questionnaire had two parts. The same situations and ranking process was involved in both parts of the questionnaire. The spearman Rank Correlation coefficient was chosen since it is a measure of association of variables ranked in two ordered series. This measure of association requires that both variables be measured in an ordinal'scale. ${ }^{6}$ This study meets this require-

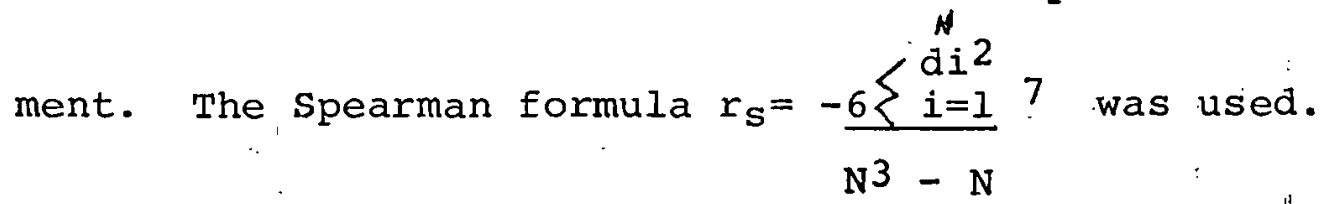
If the subjects constituted a random sample as they did in this study, one may test the significance of the $r_{s}$ using the Table of Critical Values of $\mathrm{r}_{\mathbf{s}} \cdot{ }^{8}$

A nuil hypothesis was established that there was no correlation between student answers by category between societal needs (Part I) and personal needs (Part II). An alpha level of .10 was set for this study. The results were as follows: 
Table VI

SPEARNAN RANK CORRELATION COEFFICIENT BY CATEGORIES FOR THE STUDENT QUESTIONNAIRE

\begin{tabular}{|l|c|c|}
\hline Category & $\begin{array}{c}\text { Spearman } \\
r_{\mathbf{s}}\end{array}$ & Significance \\
\hline $\begin{array}{l}\text { Close Friend- } \\
\text { Family }\end{array}$ & .8106 & .01 \\
\hline Social & .6488 & .01 \\
\hline Utility & .5194 & .01 \\
\hline $\begin{array}{l}\text { Superior- } \\
\text { Subordinate }\end{array}$ & .5588 & .01 \\
\hline \begin{tabular}{l} 
Public \\
\hline
\end{tabular}
\end{tabular}

Thus, the null hypothesis may be rejected. Indeed, it seemed there was evidence to conclude that there was a strong correlation between how students answered categorically from Part I to Part II.

A second Spearman was applied to the student questionnaire to see if there was a correlation between the answers of all students to Part I and to the answers of all students to Part II. A null hypothesis was established that there was no correlation between the subjects' answers in Part I to Part II. An alpha level of .10 was set. $N$ was equal to five as this was the number of variables possible in the ranking system. The average ranking of all students was determined by finding an average ranking for each student which were then tabulated to find an average for the entire group. The rho was found to be .4000 . This was not large enough accord- 
ing to Table $\mathrm{P}^{9}$ for the researcher to reject the null hypothesis. The evidence was not strong enough to conclude that all students' answers to Part I were correlated to their answers to Part II. This served to eliminate the fears of the planner that the students would not differentiate in answering between Part I and Part II.

The Spearman Rank Correlation Coefficients was applied to the faculty questionnaire to see if there was any correlation in answers to the three questions asked (dimensions). Since the spearman can be applied only between two ranked scales, their questions had to be tabulated against one other question at a time. Using the above procedures with an $\mathrm{N}=5$, there were null hypotheses established that there was no correlation between the answers to these questions. An alpha level of .10 was set for all three procedures.

\section{Table VII}

SPEARMAN RANK CORRELATION COEFFICIENT FOR FACULTY QUESTIONNAIRE AS TO WHAT STUDENTS NEED, WANT, AND GET FROM THE INTRODUCTORY SPEECH COURSE

\begin{tabular}{|c|c|c|c|}
\hline Questions Compared & Faculty Impression & Rho & Significance \\
\hline 5 to 6 & Needs to Wants & .9212 & .01 \\
\hline 5 to 7 & Needs to Gets & .9270 & .01 \\
\hline 6 to 7 & Wants to Gets & .9383 & .01 \\
\hline
\end{tabular}


A broad conclusion can be made on these statistical findings is that the faculty answered questions 5, 6, and 7 very. similarly. They seem to conclude that students' communicative needs and wants are met in the current introductory speech course:

Friedman Two-Way Analysis of Variance

The' third statistical procedure employed was the Friedman Two-Way Analysis. As mentioned earlier, the student questionnaire was giveín to four different groups of students. This procedure was used to find out if there was attern of similarity between the groups in their answers to the questionnaire! When the data is from matched samples in an ordinal scale, the Friedman is used to test the null hypothesis that the samples have been drawn from the same population: 10

$$
\text { Using the formula: } x_{r}{ }^{2=12}=+K \sum\left(R_{j}\right)^{2}-3 N(K+1)^{11}
$$

with the $\mathrm{K}$ standing for the conditions and the $\mathrm{N}$ for the subjects. If as in this case the $\mathrm{N}=4$ and $\mathrm{K}=5$, the associated probability may be determined by reference to the chi. Square distribution Table $\mathrm{c}^{12}$ with a df $=\mathrm{K}-1$. A null hypothes is was established that there were no difference in answers between Group I, II, III, and IV. An alpha level of .01 was set. 'The results were as "follows: 
Table VIII

FRIEDMAN TWO-WAY ANALYSIS BETWEEN

GROUP I, II, III, IV :

\begin{tabular}{|c|c|c|}
\hline & \multicolumn{2}{|c|}{} \\
\hline Part I & 13.600 & Significance \\
\hline Part II & 16.000 & .01 \\
\hline
\end{tabular}

With these results it would seem that the null hypothesis could be rejected. There is indeed a difference in answers between groups. From the spearman, we saiw that there was a pattern within the groups but from this procedure it is obvious that there is a difference in answers between the groups.

A second Friedman was used for the student questionnaire to determine if there was a similar pattern in answers between the non-transfer (Groups I, II, III) and transfer (Group IV). An alpha level of .01 was eștablished for the null hypothesis that there was a difference in the answers of the two groups. The $\mathrm{n}=2$ this time with $K=5$. Using the same procedures, the results wẹre: 
Table IX

FRIEDMAN TWO-WAY ANALYSIS BETWEEN GROUPS I, II, III, TO GROUP IV

\begin{tabular}{|l|c|c|}
\hline & Chi-Square & Significance \\
\hline Part I & 6.800 & NS \\
\hline Part II & 8.000 & NS \\
\hline
\end{tabular}

14

From these results it would seem that the null hypothesis could not be rejected. There was not a difference in answers that was significant between the non-transfer and the transfer students as a whole.

\section{SUMMARY OF RESULTS}

The statistical procedures to this point have been used to show that the questionnaires could be considered ordinal scales and that they were reliable and valid. One further statistical procedure was needed to determine the association of variables ranked in two ordered series. The comparisons to be done were between the various parts of both the student and faculty questionnaires. The statistical procedure chosen was again the Spearman Rank Correlation Coefficient as it meets the above criteria. The same procedures were applied as have been described previously in this chapter. A byproduct of the Kendali $w$ (described previously) is an average ranking for the groups. They were used in figuring these rhos. The rankings used are listed below. 
Table X

AVERAGE RANKINGS BY CATEGORIES OF THE SUBGROUPS

\begin{tabular}{|l|c|c|c|c|c|}
\hline & \multicolumn{3}{|c|}{$\begin{array}{c}\text { Students ' } \\
\text { Needs }\end{array}$} & \multicolumn{4}{c|}{ Teachers ' } \\
\hline Public & 4 & 1 & 3 & 1 & 1 \\
\hline $\begin{array}{l}\text { Superior/ } \\
\text { Subordinate }\end{array}$ & 1 & 2 & 2 & 2 & 2 \\
\hline Family & 3 & 4 & 4 & 5 & 4 \\
\hline Utility & 5 & 5 & 1 & 3 & 3 \\
\hline Social & 2 & 3 & 5 & 4 & 5 \\
\hline
\end{tabular}

The Spearman was applied once between each subgroup including both the faculty and student questionnaires. The results are shown below. 
Table XI

SPEARMAN RHOS BETWEEN SUBGROUPS OF STUDY

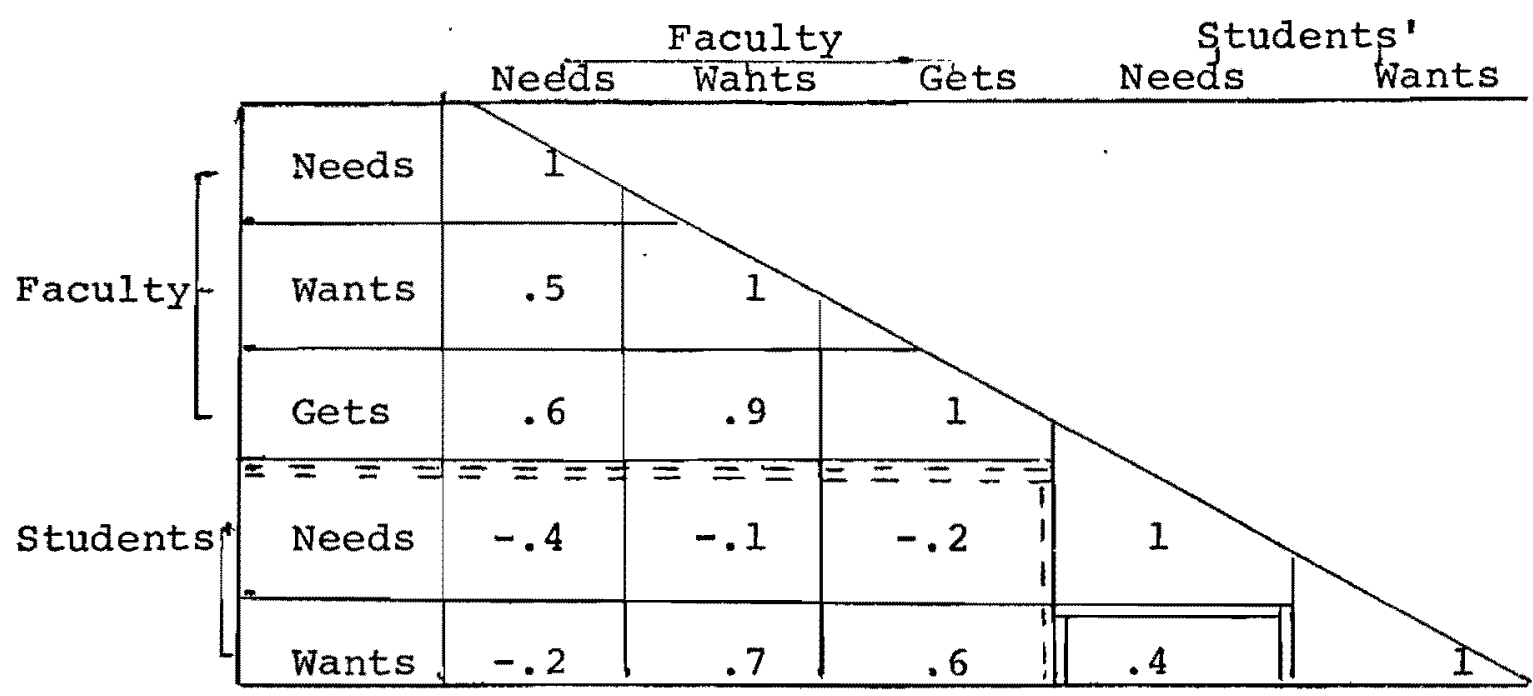

Using the Table of Critical Values of $r_{s}$, The Spearman Rank Correlation Coefficient. The following significance levels were established from the above rhos. 15

Table XII

SIGNIFICANCE LEVELS FOR SPEARMAN'S BETWEEN SUBGROUPS OF THE STUDY

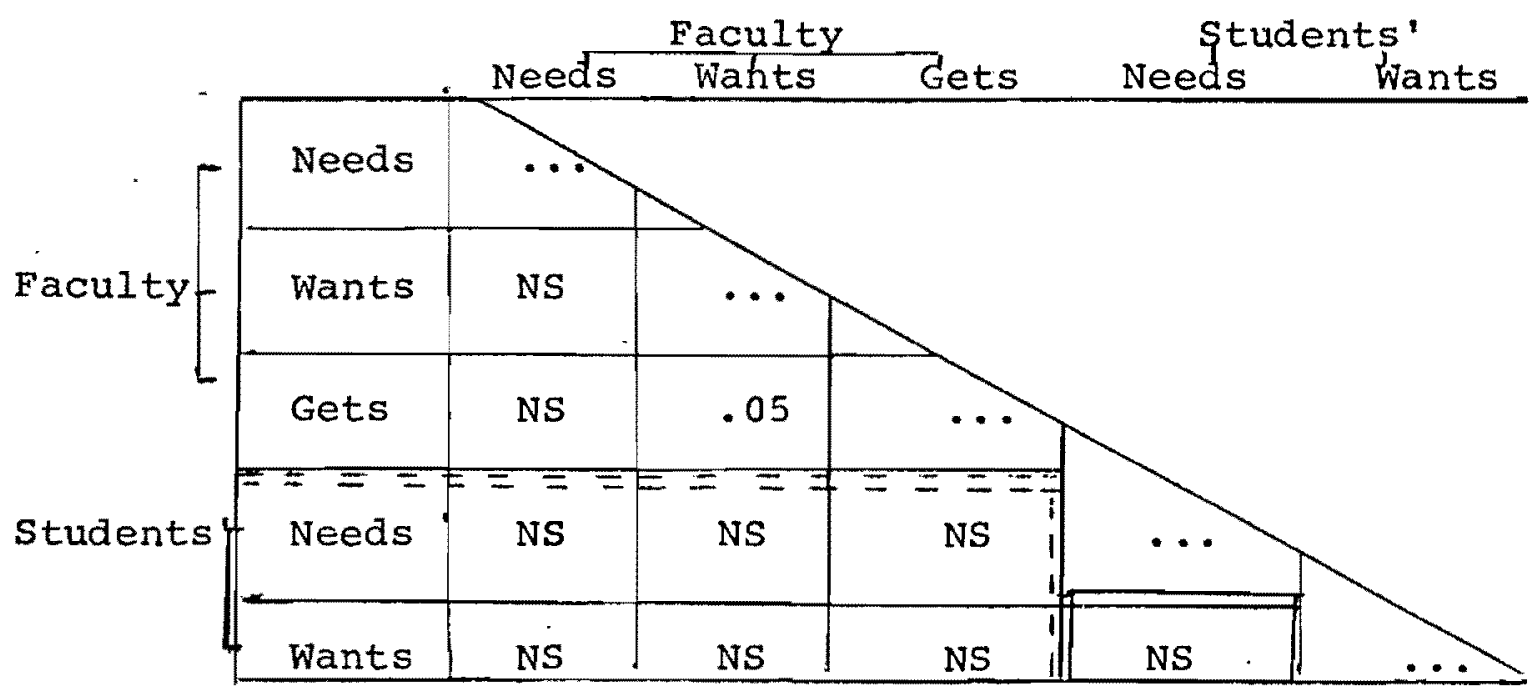


Though all of the correlation factors are not strong enough to be significant, they are strong enough for some comparisons of faculty views of what the students (1) need, (2) want, and (3) get in the introductory speech course. Those statistics in the double solid lines are those that compare student answers with other student answers. They compare how students see their needs and wants in the introductory speech course. The statistics in the single solid lines, likewise, are those that compare student answers to needs and wants to faculty perception of student needs, wants, and "gets". These statistics are perhaps the most interesting; they will be discussed first.

When comparing the answers of the students to the answers of the faculty to the needs and wants of the students in the introductory speech course there was a negative correlation between many of these. For example, there is a -.4 rho in comparing the students' interpretations of what they felt were their basic needs in the introductory speech course and what the faculty saw as students' basic needs in this same speech course. There was a consistently negative correlation when comparing what the students saw as their basic needs in the course and what faculty saw as student needs, wants, and what they got in the introductory speech course. The correlation factor became more positive in comparing what students said they wanted to get in the first speech course with what the faculty thought students wanted and got from the first speech course. However, on the whole, the correla- 
tions in this section are negative leading one to reject the first hypothesis of this study. This hypothesis being that there is a positive correlation between the basic assumptions of the introductory speech course as seen by the speech faculty and the basic assumptions of the introductory speech course as seen by the students in the introductory speech course.

It does not seem that there is enough evidence to say that there is a very strong relationship between part I and Part II of the student questionnaire. Both Spearman rhos applied (the one listed in the table being discussed and the one that was discussed earlier in this chapter) came out to a .4000 correlation. This is not strong enough to show a correlation between what students feel their needs and wants are in the introductory speech course. Using the significance level as the determining factor, it would seem that the second hypothesis could be weakly rejected. This hypothesis stated that there was a positive correlation between what students felt they; needed to improve in needs communicative-wise in the introductory speech course and what they felt was most important for them to do well in communicative-wise (wants). However, the evidence does not allow the author to make this conclusion a very definite one.

The statistics in the dotted line area show a fairly strong, though not always significant, relationship between how the faculty viewed the students' needs, wants, and what they got from the introductory speech course. Couple these 
Spearman rhos listed in the table with the Spearman's discussed earlier in this chapter between students needs, wants, and what they got in the speech course, and it is strong enough to formulate the idea that there is indeed a relationship between the faculty answers to these three questions. The first set of Spearman's were all significant in showing a relationship. In this second set of spearman's the only one strong onough to show a .05 significance level was the comparison between what faculty saw as student wants in the course and what they felt that students got in the course. The rho here was .90 . It would seem then that at least the evidence does not point to rejecting the III, IV, and V hypotheses of this study. Therefore, it would seem that we could accept:

Hypothesis III: There is a high degree of consistency between what the speech faculty feel are student's needs in communication in the introductory speech course and what they perceive that students get from the introductory speech course.

Hypothesis IV: There is a high degree of consistency between what speech faculty feel that students' needs are in commuication in the introductory speech course and how the faculty perceive what students deem as their communicative needs.

Hypothesis $V$ : There is a high degree of consistency between what the speech faculty feel students deem as their communicative needs in the introductory speech course and what they perceive that students get from the introductory speech course.

Therefore, we reject the first two hypotheses and accept the last three. 
Footnotes

1. Sidney Siegel, Nonparametric Statistics For the Behavioral Sciences, (New York: MCGraw-Hill Book Co., Inc., 1956), pp. 229-239.

2. Ibid, pp. 203-213.

3. Ibid; pp. 166-173.

4. Ibid; p. 237.

5. Ibid; p. 236 .

6. Ibid, p. 202 .

7. Ibid, p. 204 .

8. Ibid; p. 284 .

9. Ibid, p. 284 .

10. Ibid, p. 166.

11. Ibid, p. 168 .

12. Ibid, p. 249.

13. Ibia.

14: Ibia.

15. Ibid, p. 284 . 


\section{CHAPTER V}

\section{SUMMARY AND CONCLUSIONS}

This final chapter will summarize and interpret the experimental results of the study. The research hypotheses will be reviewed, relevant results will be restated, and conclusions drawn. Suggestions for further research will conclude this chapter.

\section{SUMMARY}

The specific question which this study was designed to investigate was: To what extent are the underlying assumptions of the basic speech courses at the community college level as seen by the instructors similar to or different from the self-reported needs in communication training of the community college students?

The study was based on the assumption that by asking both the students and the speech faculty what they felt the needs of the student are in the introductory course that a series of correlations could be established for comparison. Also, it was assumed that the answers of the two groups would be indicative of the basic underlying assumptions of speech needs of these groups. In terms of these assumptions, hypotheses were generated to compare the correlation factors between the students' and faculty's answers to the questions on 
student needs.

However, first to be assessed before the hypotheses could be tested was the validity of the testing instruments. The test instruments for both the faculty and students were developed using categories and communicative situations discovered through pre-test data. The two questionnaires were designed to be similar so that results ofbtained could be compared. All tests applied to these instruments proved them to be valid and reliable. It was concluded that they could be considered to be scales for determining needs in communication.

Once the test validity was established, the first hypothesi's to be tested was:

Hypothesi's I: There is a positive correlation between the basic assumptions of the introductory speech. course as seen by the speech instructor and the student-felt needs in this course.

Hypothesis I failed to be confirmed. There is no significant correlation between what the faculty think are the basic needs of the introductory speech course and what the students feel the basic needs of the course are. In fact, in most of the comparisons between the various sections of the students' and faculty's questionnajres there were negative correlations. This would indicate that there is no agreement between the students and the faculty as to what the students need to receive in training in the introductory speech coürse. An explanation of this result could be one of 
many, such as: 1) There is little communication between the speech faculty and the students as to what should be done in the introductory speech course. This could be because the faculty do not feel that the students would know what is best for them to learn in communicative skills. 2) It could be that, indeed, the students do not know what is best for them to improve in communicative-wise. 3) It could be that the administration of the various community colleges control the course emphasis in these courses. Thus, the instructors are not allowed to respond to the needs they feel are relevant or that the students express.

A second area of interest in this study was whether students wolid agree between themselves about their need to improve in communication and what they felt was important for them to do well in. Thus, a second hypothesis evolved: Hypothesis II: There is a positive correlation between what students feel they need to improve in communi-. cative-wise (personal needs) in the introductory course and what they feel is most important for them to do well in communicative-wise (societal need's).

This hypothesis also failed to be confirmed. The correlation between these two sections of the student's questionnaire was not strong enough to be considered significant. It does seem that students do see the need to improve communicative-wise as a separate need from the personal need of what they feel is most important for them to do well in communica- 
tive-wise. The students do seem to have this discriminating ability which would have a direct affect on curriçulum planning. It would appear that students do have a fairly definite idea as to what they would like to be presented in the introductory speech course, if they were asked.

It is also interesting to note that the statistics show that there was a similarity of answers within each subgroup of students questioned but that there did seem to be a difference in choices between the subgroups which represented various schools and locations. There are different needs in communication for students in different community settings.

A similar comparison seemed necessary with the faculty questionnaire to determine if there was any correlation among Oregon speech faculty as to what they felt that students wanted in the introductory speech course; what they got from the course; and what students actually needed to improve in. Three hypotheses emerged from this comparison, the first being: Hypothesis III: There is a high degree of consistency between what the speech faculty feel are students' needs in communication in the introductory speech course and what they perceive that students get from the introductory speech course.

This hypothesis seemingly can be accepted. There were two sets of statistics used to come to this conclusion. The first set showed a significant correlation between what faculty answered as students' needs and what they get in the 
course. The second set, though it did not show a significant correlation, showed a fairly strong one. Thus, it appears that there is a relationship between what the faculty feel that studênts need and get. Obviously, it appears that the faculty feels that the students are getting what they feel they need from the introductory course. Thus, it would seem that the faculty are fairly satisfied with the course as taught.

The second hypothesis dealing, with a comparison of faculty answers attempted to find a correlation between what the instructors felt students needed versus what students actually wanted from the introductory course. The hypothesis stated:

Hypothesis IV: There is a high degree of consistency between what speech faculty feel that students' needs are in communication in the introductory speech course and how the faculty perceive what students deem as their communicative needs.

This hypothesis can also be accepted. The reasons for this acceptance are the same as listed immediately above. From this it appears that the faculty think that they are in agreement with the students as to: what they need to teach in the introductory course. This would seem to be an indication that the instructors feel that they are in tune with students and know their feelings. However, the findings of the first hypothesis show this to be a faulty assumption. 
The last hypothesis dealing with the faculty compares the perceptions of the instructor as to what he feels that students want to get from the course with what they are actually getting. The hypothesis reads: Hypothesis V: There is a high degree of consistency between what the speech faculty feel students deem as their communicative needs, in the introductory course and what they perceive that students get from the introductory course.

This hypothesis can be accepted for the same reasons as listed above. From this it seems that the faculty believe that the students get what students want from the introductory course. However, this is not the case as seen above.

From the above three hypotheses combined it appears that the faculty think that the current course in speech is giving the students what they want and need. However, there is an obvious discrepancy between what the students themselves feel their wants and needs are in communication and what the faculty deem them to be.

\section{CONCLUSIONS}

The results of this study have produced some highly significant findings: The one obvious conclusion of this study is that the speech faculty and perhaps the whole institution of education is not communicating with the student population as to what should be offered in the courses these. same students are required to take. It comes from the 
philosophy that the teacher and/or school knows what is best for the student to learn in any given cllass. The present method of curriculum development and planning in the school system usually has no formal method of getting student input. often the course content is for all purposes dictated, at least partially, by educators no longer in the classroom. For the community college policy is set by the needs of the four-year colleges in the area to which most of the student population may transfer.

Interesting in light of the findngs of the present study were some of the comments by the speech faculty when asked in their questionnaire if they were satisfied with how the course was presently taught. Twenty out of the twentyseven questionnaires received from speech faculty in oregon indicated an emphasis on public speaking in the introductory course. Knowing this addition to the results of the study showing that the faculty pretty well think they are meeting student needs with the course as presently taught, these comments made by faculty were interesting:

I would like more time to work with individual students defining their problems and helping them on a one to one ratio.

I am never totally satisfied with the speech course; consequently, I am continuously making changes. Generally, I have found that students who take speech expect to study and give public speeches.

Frequently our speech classes are so large that students are limited in the number of speeches they give. 
There is always room for change and I am continually changing how I go about things. The basic goal remains constant, i.e. to give students confidence in themselves and help them to feel secure enough about themselves to give themselves to others on all levels.

We are changing each quarter as we see better methods but our goals have not changed.

Although we are constantly revising the course to keep it updated, the general format is satisfactory. All instructors aim for the same ultimate goals to be able to clearly develop, organize, deliver, and receive an informative message. Our methods of reaching that goal area are quite flexible and individual.

In giving these comments, it is only fair to say that several instructors who indicated that their emphasis was public speaking expressed a desire to change the first course to include other areas of communication such as: social, utility, superior/subordinate, and close friends levels. It does seem that perhaps the trend of what is taught in the first course may change. However, there is little to evidence that the students will have much say in this change.

III. SUGGESTIONS FOR FURTHER RESEARCH

Four areas of research, revealed during the course of this study, deserve prompt attention. Each will be listed and discussed in turn.

1. A description of the current curriculum and methodology used in the introductory speech courses both at the community college and four-year college level is needed. Although a lot of assumptions are made by faculty and other educators about what the current trends are in speech 
education, little research has been done to see if these courses are keeping up with what the journals claim to be new trends in speech education. Indeed, it seems the first course has not changed its basic goals in the last several years. The description of current curricula cited in this study is only a partial indication of what the community colleges are doing there is no description of the four-year college curriculum.

2. An analysis of what student needs are in the area of communication is needed. This study attempted to identify the neeas of students in communication. It makes no claim, however, of being an in-depth study of these needs. For one thing, a much more sophisticated testing device is needed to be sure that all need areas are being considered. Also, the sample of students tested should be much more extensive than this one. While it is a difficult concept to analyze, it would seem that other researchers could have tapped this area.

3. A study into curriculum development that would best meet student-felt needs in the introductory speech course is needed. Of course, the assumption of this suggested study is that it would be completed only after the preceding two areas of study had been completed. Needless to say, it would be to everyone's advantage if the first course were taught in the way that could best meet everyone's needs. This study would have to include a complete summary of all the literature in the journals concerning new and innovative ways to teach 
speech. It might also have to incorporate some creative thinking on the part of its authors to develop methods of teaching need areas perhaps not presently known or used in the introductory speech course. Most importantly, there must be some technique instituted to allow student input into curriculum development.

\section{LIMITATIONS OF THE STUDY}

When trying to study behavioral aspects of learning with a statistical oriented testing device, there are inherent limitations in any study. This study is not excluded from these limitations. The subjects in this study are asked to respond to situations involving their personal needs as students and faculty with a simple number response. The rationale for the ranking system was to force the respondents to think in. terms of priorities in their needs as communicators. Hopefully this was accomplished. Also, it was a practical way to get data that could be analyzed.

Also, the very nature of the testing device brings out several other limitations that were considered prior to the study. First there is a problem of wording without including test bias in the questionnaire. The question arises as to what emotional responses may have occurred with the students and faculty when reading the communicative situations listed in the rankings. Included in this consideration must be the question of how well the students and faculty understood the directions to the study. Finally, there must be some thought 
given to what ran through the minds of the respondents when they were asked to fill out the questionnaire. What, indeed, did they see the purpose of this study to be.

The study was, also, limited in the population from which the subjects were chosen. It was not possible to question all students in the community college taking the introductory speech course for practical reasons. Therefore, a decision was made to take a sample from three community colleges to serve as a cross section of the community colleges in Oregon. The choice of who was tested at these institutions was random other than the fact that the students were all enrolled in an introductory speech course. The entire population of speech faculty in oregon community colleges were sent a questionnaire to be answered.

Another limitation involved the questionnaire administrator biasing the results in administration of the student questionniare. Therefore, it was decided to do two things to circumvent this. First, a set of written directions was given to the student. The test administrator was advised to only clarify these directions. Secondly, the study was administered to the student segment the first day of the introductory speech class so that the present speech instructor would not have time to bias the students' concepts. Students were also allowed to remain anonymous to make sure that they did not feel any pressure in their answers.

There were similar limitations involved in the testing device sent to the speech faculty of the oregon community 
colleges. It was not possible to let these people remain anonymous so that the representation of the colleges could be determined. Thus, some influence in their answers must be attributed to the fact that these people were apt to say some things to enhance their own personal position. Thus, all conclusions drawn will be subject to these limitations. 


\section{A SELECTED BIBLIOGRAPHY}

Applbaum, Ron and Willis Hays. "Speech Education in California Public High Schools: Implications for Teacher Preparation and Curriculum Trends," Western Speech Journal, XXXV, Winter 1971, 56-62.

Brooks, William and Sarah Platz. "The Effects of Speech Training Upon Self-Concept As a Communicator," The Speech Teacher, January 1968, 44-49.

Campbel1, Paul. "Performance: The Pursuit of Folly," The Speech Teacher, 20, November 1971, 263-274.

Dedmon, Donald and Kenneth Frandsen. "The Required First Course In Speech: A Survey," The Speech Teacher, January $1964,32-39$.

Friar, Don. "Methods and Trends in the Junior College Basic Speech Course," Western Speech Journal, Spring 1970, 148-153.

Freshley, Dwight and Don Richardson. "Student Evaluation of Basic Speech Courses," The Southern Speech Journal, XXXIV, Winter $1968,85-\overline{93}$.

Gibson, James, Charles Gruner, William Brooks, and Charles Petrie Jr. "The First Course In Speech: A Survey of US Colleges and Universities," The Speech Teacher, January 1970, 13-20.

Kelley, william. "Speech Instruction in California Community Colleges," The Speech Teacher, September 1970, 211-223.

McCroskey, James C. "The Effect of the Basic Speech Course on Student's Attitudes," The Speech Teacher, March $1967,115-117$.

Mandel, Jerry and Ron Applbaum. "An Investigation of Student Preferences: Basic Speech Course Titles and Descriptions," The Speech Teacher, March 1971, 146-148.

Markgraf, Bruce. "The First Course in Speech," Western Speech Journal, Spring 1969, 92-1ll.

Mehrley, R. Samuel and James C. Backes. "The First Course in Speech: A Call for Revolution," The Speech Teacher, XXI, September 1972, 205-210.

Schmeller, Kurt R. "Speech and the Community College," Western Speech Journa1, Fall 1972, 5-7. 
Siegel, Sidney. Nonparametric Statistics For the Behavioral Sciences, New York, New York: McGraw-Hill Book Co., Inc., 1956.

Thompson, William P. "Speech In a Community College;" Western Speech Journal, Fall 1972, 2-4.

Wolvin, Darlyn and Andrew Wolvin. "The Speech Communication Curriculum in the Community College," Western Speech Journal, Fall 1972, 9-13. 
APPENDIX 
TO STUDENTS: Please fill out this questionnaire as completely and honestly as possible. It is part of a study being done to determine what students want and need from their introductory speech courses. Your help on this project is greatly appreciated. Ask the administrator if you have any questions as to directions.

\section{STUDENT QUESTIONNAIRE \\ Part I}

DIRECTIONS: Rank the following communication situations from 1 (highest) through 5 (lowest) in each group in their order of importance to you. In this section of the questionnaire you should judge which kinds of communication situations are most important for you to do well in.

Most

important

to you

1. Situations like:

A. Talking with a teacher about a mistake on a test.

B. Talking with parents or a close fried about a problem with another friend.

C. Giving a speech to a Rotary club meeting.

D. Talking over coffee with a group of fellow students or co-workers.

E. Giving directions to strangers on how to get to another town.

2. Situations like:

A. Talking with door-to-door salesmen when they come to your home.

B. Making small talk at a party.

C. Going to a family reunion and talking with relatives.

D. Giving prepared talks in front of groups of people you don't know.

E. Talking with your boss about a raise.

3. Situations like:

A. Talking with your father or close family member about your goals in life.

B. Accepting an award at a banquet.

C. Entertaining guests at your home.

D. Telling the Dean of Students about a change in policy you think is necessary.

E. Talking to bank tellers about deposit errors on your account.

4. Situations like:

A. Conversing with your grandfather or other relative about your hobby. 
Most

important

to you

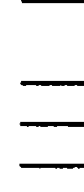

B. Making a presentation of a new idea at a stockholders meeting of a company.

C. Asking clerks in a store where something is.

D. Interviewing for a job.

E. Organizing some recreation with people you know.

5. Situations like:
A. Talking with your best friend about a serious matter.
B. Talking over ideas with several classmates or co-workers.
c. Asking gas station attendants for instructions on how to get somewhere.
D. Reading the minutes of a club at the meeting.
E. Discussing a change you feel should be made in company policy with your boss.

6. Situations like:

A. Asking strangers for help. haven't seen for a year or more.

c. Introducing the main speaker at a company conference.

D. Trying to convince your mother (father) or close family friend that they have made a mistake in judging your actions.

E. Convincing bankers they should give you those loans you need.

7. Situations like:

A. Discussing job deficiencies with someone who works under you.

B. Answering the telephone at a place of business.

C. Keeping the conversations moving during luncheon dates.

D. Talking with your aunt from out-of-town about family problems.

E. Giving a talk to a group to convince them to vote for you in the upcoming company/school election.

8. Situations like:

A. Discussing your views on controversial issues with a close family friend.

B. Starting up a conversation with someone you've never talked to before.

C. Explaining to TV repairmen what is wrong with your television set.

D. Standing up and presenting your ideas at a 
Most

important

to you community meeting.

E. Talking to a policeman that pulls you over to the side of the road for a violation. 
STUDENT QUESTIONNAIRE

Part II

DIRECTIONS: Rank the following communication situations from 1 (highest) through 5 (lowest) in the order which you feel you need the most improvement in. In this section of the questionnaire you must judge which kinds of communication situations you need to improve the most in.

Need

most

improvement

1. Situations like:

A. Talking with a teacher about a mistake on a test.

B. Talking with parents or a close friend about a problem with another friend.

C. Giving a speech to a Rotary club Meeting.

D. Talking over coffee with a group of fellow students or co-workers.

E. Giving directions to strangers on how to get to another town.

2. Situations like:

A. Talking with door-to-door salesmen when they come to your home.

B. Making small talk at a party.

C. Going to a family reunion and talking with relatives.

D. Giving prepared talks in front of groups of people you don't know.

E. Talking with your boss about a raise.

3. Situations like:

A. Talking with your father or close family member about your goals in life.

B. Accepting an award at a banquet.

C. Entertaining guests at your home.

D. Telling the Dean of students about a change in policy you think is necessary.

E. Talking to bank tellers about deposit errors on your account.

4. Situations like:

A. Conversing with your grandfather or other relative about your hobby.

B. Making a presentation of a new idea at a stockholders meeting of a company.

C. Asking clerks in a store where something is.

D. Interviewing for a job.

E. Organizing some recreation with people you know. 
Need

most

improvement

5. Situations like:

A. Talking with your best friend about a serious matter.

B. Talking over your ideas with several classmates or co-workers.

c. Asking gas station attendants for instructions on how to get somewhere.

D. Reading the minutes of a club at the meeting.

E. Discussing a change you feel should be made in company policy with your boss.

6. Situations like:

A. Asking strangers for help:

B. Making conversations with acquaintances you haven't seen for a year or more.

c. Introducing the main speaker at a company conference.

D. Trying to convince your mother (father) or close family friend that they have made a mistake in judging your actions.

E. Convincing bankers they should give you those loans you need.

7. Situations like:

A. Discussing job deficiencies with someone who works under you.

B. Answering the telephone at a place of business.

C. Keeping the conversations moving during luncheon dates.

D. Talking with your aunt from out-of-town about family problems.

E. Giving a talk to a group to convince them to vote for you in the upcoming company/school election.

8. Situations like:

A. Discussing your views on controversial issues with a close family friend.

B. Starting up a conversation with someone you've never talked to before.

C. Explaining to a TV repairman what is wrong with your television set.

D. Standing up and presenting your ideas at a community meeting.

E. Talking to a policeman that pulls you over to the side of the road. for a violation. 
(Example)

Instructor's Name Speech Department . Community College Address

Dear

I need your help to complete a study that could be beneficial to both of us. I am presently conducting a research study into the curriculum used in the oregon community college speech classroom. Perhaps this study will result in development of new methodology in the teaching of speech.

However to complete my research, I need feedback from as many speech and communications teachers in the community colleges as possible. The success of the project depends on this! Please take ten minutes to fill out the enclosed questionnaire. A return envelope is provided for your convenience.

Thank you for your help!

sincerely yours,

Vickie Hilgemann

Speech/Communications Instructor

$\mathrm{VH} / 1 \mathrm{~d}$ 


\section{Name \\ School}

FACULTY QUESTIONNAIRE :

DIRECTIONS: Please fill out as indicated in each question. Send back in the envelope provided as són as possible. Please include any assignment sheets or class objectives you have available for the course also.

1. Is this basic speech class for:

\section{A. College Transfer}

B. Vocational/Technical

C. Both

D. Other

2. Is this course required for graduation? YES NO

3. Does the school or department have a policy regarding. what is to be covered in the basic speech class. YES NO

If yes, which best describes the emphasis of this policy. (Check one)

A. Public speaking

B. Interpersonal Communication

C. Intrapersonal Communication

D. Other

4. What is the basic emphasis of the textbook as you see it? (Check one)

A. Public speaking

B. Interpersonal Communication

C. Intrapersonal Communication

D. Other

5. What do YOU FEEL are the basic needs of your students as communicators?. RANK IN ORDER OF IMPORTANCE TO YOU. (Use $1-5$ or 6 as needed)

A. To be able to communicate effectively in a public situation.

B. To be able to communicate effectively with one's superiors/subordinates.

c. To be able to communicate effectively with family and close friends.

D. To be able to communicate effectively with others on a utility level. (Eg. to elicit from or give directions, instructions, explanations, etc.) 
E. To be able to communicate effectively on a social level. (Eg. casually with peers)

F. Other (if relevant)

6. What do YOU FEEL the STUDENTS WANT from the introductory speech class. RANK IN ORDER OF IMPORTANCE AS YOU VIEW IT.

A. To be able to communicate effectively in a public situation.

B. To be able to communicate effect'ively with one's superiors/subordinates.

c. To be able to communicate effectively with family and close friends.

D. To be able to communicate effectively with others on a utility level. (Eg. to elicit from or give directions, instructions, explanations, etc.)

E. To be able to communicate effectively on a social level. (Eg. casually with peers)

F. Other (if relevant)

7. What do YOU FEEL the STUDENTS GET from the introductory course in speech. RANK IN ORDER OF IMPORTANCE AS YOU SEE IT.

A. To be able to communicate effectively in a public situation.

B. To be able to communicate effectively with one's superiors/subordinates.

c. To be able to communicate effctively with family and close friends.

D. To be able to communicate effectively with others on a utility level. (Eg, to elicit from or give directions, instructions, explanations, etc.)

E. To be able to communicate effectively on a social level. (Eg. casually with peers)

F. Other (if relevant)

8. Are you satisfied with the course as it is taught now? YES NO

If not, how would you change it if possible? 